\title{
コンクリートへの塩化物イオンの侵入と 中性化による複合作用の評価に関する研究
}

\author{
堺 孝司*1 $\cdot$ 大森 正貴 $*^{2} \cdot$ Mohamed Boulfiza $*^{3}$
}

\begin{abstract}
概要 : 塩化物イオンの侵入と中性化による複合作用に関する研究において, コンクリート供試体による定量的評価は 十分ではない。そこで本研究では, 実験および解析により, コンクリート中における塩化物イオンの浸透・拡散性状 と中性化による複合作用に関する基礎的情報を得るとともに，塩化物イオンの侵入と中性化による複合作用の評価手 法を検討した。その結果，塩化物イオンを含むコンクリートは中性化により内部への拡散が促進され，実際の暴露期 間よりも長い暴露期間に相当する塩化物イオンが浸透していることが分かった。そこで本論文では, Fickの第 2 法則 に基づく拡散方程式の解に中性化の影響を考慮する係数 $k$ を暴露期間 $t$ に乗ずる方法を提案した。 キーワード : 塩化物イオン, 中性化, 複合作用, Fick の拡散方程式
\end{abstract}

\section{1. はじめに}

コンクリートの耐久性問題には様々な側面があるが, 塩害と中性化はその中でも特に重要な劣化現象といえ る。また, 現在では複数の劣化作用が複合して生じる複 合劣化が注目されており, 塩害と中性化による複合劣化 についても研究がなされている。

小林ら ${ }^{1)}$ は, モルタル供試体を用いた実験により, 塩 化物イオンが中性化の進行によって以下のような過程で 内部に濃縮し，鉄筋の腐食を促進する可能性があること を 1991 年に既に明らかにしている。

(1)セメント中の化合物の一つであるアルミネート層が

十分な石膏と反応してエトリンガイトを生成する。

(2)未反応のアルミネート層がエトリンガイトと反応し てモノサルフェートを生成する。

(3)塩化物イオンはこのモノサルフェートと反応してフ リーデル氏塩などとして固定化される。

(4)中性化が進行すると固定化された塩化物イオンが再 びイオン化して細孔溶液中に遊離する。

(5)中性化領域と未中性化領域での濃度勾配が大きくな り，未中性化領域に塩化物イオンが拡散して，内部 に濃縮して，鋼材の腐食を促進する。

また，佐伯ら ${ }^{2)}$ は中性化モデルおよび塩分浸透モデル を組み合わせることで塩害と中性化が同時に起る場合の 複合劣化進行予測モデルを構築している。中性化進行予 測モデルでは, 水, 二酸化炭素 (気相, 液相), 水酸化力
ルシウムのコンクリート中での移動と反応を考慮し, 塩 化物イオン浸透予測モデルには塩分の拡散・移流を考慮 に入れている。これらのモデルを組み合せたものを用い て, 中性化と塩害が複合した場合の塩化物イオン濃度の 予測を行ったところ，炭酸化による塩分濃縮を捉えると ともにモルタル供試体を用いた実験值と計算值もよく一 致する結果となった。

一方, Boulfiza $ら^{3)}$ は, 中性化と塩化物イオン浸透の 複合効果に関する解析的検討を行っている。

塩化物イオンの拡散や塩害に関しては多くの研究例えば

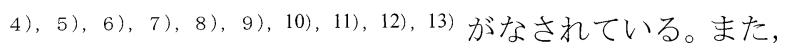
セメントによる塩化物イオンの固定に関しても多くの研 究 ${ }^{14)}$ がなされている。しかしながら, 中性化と塩害の 複合劣化に関する実験的および解析的研究は, 上述の佐 伯らおよび Boulfiza らによる研究以外に見あたらない。 佐伯らの研究における塩分固定・解離のモデル化の検討 には合成モノサルフェートを用い，モルタルによりモデ ルの検証を行っているが, 実用レベルまでの展開になっ ていない。現在, 塩化物イオンの浸透と中性化は実務的 にはそれぞれ分離して扱っており，これらの複合作用効 果を実用的なレベルで統合的に扱う手法が望まれる。

そこで，本論文では，先ずコンクリート供試体を用い た実験により, 塩化物イオンの侵入と中性化による複合 作用についての定量的な検討を行うとともに，それらの 結果と有限要素法による解析との比較を行う。次に, 塩 害と中性化の複合効果に関する評価方法の一つとして,

*1 香川大学教授 工学部工学部安全システム建設工学科 工博 (正会員) †761-0396 香川県高松市林町 2217-20

*2 株式会社 間組 横浜支店土木部 $\overline{7} 231-8417$ 横浜市中区元浜町 3-21-2

*3 Department of Civil Engineering, University of Saskatchewan, Associate Prof., 57 Campus Drive, Saskatoon, SK, Canada S7N 5A9. 
Fickの第 2 法則の解である式(1)に中性化の影響を考慮に 入れる方法を検討する。

$$
C=C_{0}\left\{1-\operatorname{erf}\left(\frac{c}{2 \sqrt{D_{d} \cdot t}}\right)\right\}
$$

ここに，C: 深さ $c$ における塩化物イオン濃度 $(\%)$

$C_{0}:$ 表面塩化物イオン濃度 $(\%)$

$c:$ 表面からの深さ $(\mathrm{cm})$

$D_{d}:$ 拡散係数 $\left(\mathrm{cm}^{2} /\right.$ 年 $)$

$t:$ 暴露期間 $($ 年)

erf : 誤差関数

\section{2. 実験的検討}

\section{1 使用材料および配合}

セメントは普通ポルトランドセメント（密度 $3.16 \mathrm{~g} / \mathrm{cm}^{3}$, 比表面積 $3300 \mathrm{~cm}^{2} / \mathrm{g}$ ), 細骨材に砂岩砕砂（表 乾密度 $2.55 \mathrm{~g} / \mathrm{cm}^{3}$, 粗粒率 2.72 , 吸水率 $2.24 \%$ ), 粗骨 材には砂岩砕石を 2015 (表乾密度 $2.57 \mathrm{~g} / \mathrm{cm}^{3}$, 粗粒率 7.20 , 吸水率 $2.16 \%$ ） と 1505 （表乾密度 $2.56 \mathrm{~g} / \mathrm{cm}^{3}$, 粗 粒率 5.93, 吸水率 $2.32 \%$ ）を $4: 6$ の割合で用いた。表-1 にコンクリートの配合を示す。水セメント比を $40 \%, 50 \%$, $60 \%$ とし，目標スランプを $8 \pm 1.5 \mathrm{~cm}$, 目標空気量を 4.5 土1.0\%とした。

\section{2 実験方法}

供試体は $10 \times 10 \times 40 \mathrm{~cm}$ の角柱供試体とし, 打設面に対 して垂直な $10 \times 40 \mathrm{~cm}$ の側面 1 つを開放面としてそれ以外 の 5 面はエポキシ樹脂によるシーリングを施した。中性 化と塩化物イオンの浸透による複合作用として二つのシ リーズを設定した。まず，Series I は供試体に塩水によ る乾湿の繰返しを作用させてから中性化を促進させるも の, Series II は中性化を促進させてから塩水による乾湿 の繰返しを作用させるものである。塩化物イオン濃度は 深さ方向に対して $1 \mathrm{~cm}$ 間隔で測定を行った。図-1に Series I の実験フロー図を, 図-2 に Series II の実験フロ 一図を示す。なお，本来は実環境作用を実験条件として 設定することが望ましいが，実際には困難であるので，
ここでは単純化した環境作用条件での基本的な情報を得 ることとした。

\section{3 供試体および試験条件}

表-2 に供試体の概要を示す。塩水による乾湿繰返し条 件は，1 サイクルにつき塩水浸漬期間 2 日間, 乾燥期間 4 日間を基本とするが，(7)よび(8)については塩水浸漬期 間をそれぞれ 1 日間，8時間とし，乾燥期間をそれぞれ 2 日間，16 時間とした。また，乾湿繰返しサイクル数は 15 サイクルを基本とするが，(5)およ゙6)についてはそれぞ れ 10 サイクルと 5 サイクルとした。また, 水セメント比 ごとに促進中性化の代わりに気中暴露を行うケース (1), (3)，(9) を設定した。促進中性化期間および気中暴露期 間は $40 \%$ の供試体は 0 週と 8 週，50\%は0 週，4 週およ び 8 週，60\%は 0 週，1 週，4 週および 8 週とした。表-3 に試験条件を示す。

\section{4 試験項目}

\section{（1）中性化深さ測定}

中性化深さの測定は供試体を浸透面に対して垂直に割 裂し, 直ちにその割裂面にフェノールフタレイン $1 \%$ 溶 液を吹き付け，非発色部を中性化部とした５点を測定 し，その平均を中性化深さとした。

\section{(2) 塩化物イオン濃度測定}

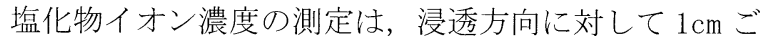
とに，塩化物イオンの溶出を防ぐために乾式のコンクリ ートカッターでスライスし, JIS A 1154 『硬化コンクリ 一ト中に含まれる塩化物イオンの試験方法』に準じて全 塩化物イオン濃度と可溶性塩化物イオン濃度の測定を行 った。固定塩化物イオン濃度は全塩化物イオン濃度から 可溶性塩化物イオン濃度を差し引いたものとした。

\section{（3）細孔径分布測定}

Series I，II それぞれの(10および(11)の中性化 4 週の供試 体について表面から深さ $1 \mathrm{~cm}$ までの層の細孔径分布の測 定を行った。測定用試料は塩分測定用試料を作成する際 に粗砕した供試体から粗骨材を除去した後, 2. 5〜 5 mm の 大きさのモルタル部分とした。測定は，水銀圧入式ポロ シメータを用いて行った。

表-1 コンクリートの配合表

\begin{tabular}{|c|c|c|c|c|c|c|c|c|c|c|c|c|c|}
\hline \multirow{3}{*}{$\begin{array}{l}W / C \\
(\%)\end{array}$} & \multirow{3}{*}{$\begin{array}{l}\mathrm{s} / \mathrm{a} \\
(\%)\end{array}$} & \multicolumn{5}{|c|}{ 単位容積質量 $\left(\mathrm{kg} / \mathrm{m}^{3}\right)$} & \multirow{3}{*}{$\begin{array}{l}\mathrm{AE} \text { 剂 } \\
(\mathrm{C} \times \%)\end{array}$} & \multirow{3}{*}{$\begin{array}{c}\text { 高性能 } \\
\mathrm{AE} \text { 減水剤 } \\
(\mathrm{C} \times \%)\end{array}$} & \multirow{3}{*}{$\begin{array}{l}\text { スラ } \\
\text { ンプ } \\
(\mathrm{cm})\end{array}$} & \multirow{3}{*}{$\begin{array}{c}\text { 空気量 } \\
\text { (\%) }\end{array}$} & \multirow{2}{*}{\multicolumn{3}{|c|}{$\begin{array}{c}\text { 圧縮強度 } \\
\left(\mathrm{N} / \mathrm{mm}^{2}\right)\end{array}$}} \\
\hline & & \multirow{2}{*}{ W } & \multirow{2}{*}{$\mathrm{C}$} & \multirow{2}{*}{ S } & \multirow{2}{*}{2015} & \multirow{2}{*}{1505} & & & & & & & \\
\hline & & & & & & & & & & & 7 日 & 28 日 & 91 日 \\
\hline 40 & 42 & 168 & 420 & 701 & 390 & 583 & 1.0 & 0.25 & 8.1 & 4.3 & 55.4 & 69.3 & 71.7 \\
\hline 50 & 42 & 168 & 336 & 729 & 406 & 606 & 1.0 & 0.23 & 8.5 & 4.7 & 40.8 & 50.2 & 53.8 \\
\hline 60 & 43 & 171 & 285 & 761 & 407 & 607 & 1.0 & 0.35 & 7.5 & 4.5 & 30.8 & 39.7 & 42.9 \\
\hline
\end{tabular}


表-2 供試体概要

\begin{tabular}{|c|c|c|c|c|c|c|}
\hline \multirow{2}{*}{ 供試体番号 } & \multirow{2}{*}{$\begin{array}{l}\text { W/C } \\
(\%)\end{array}$} & \multicolumn{3}{|c|}{ 塩水による乾湿繰返し } & \multirow{2}{*}{$\begin{array}{l}\text { 中性化促進 } \\
\text { 期間（週） }\end{array}$} & \multirow{2}{*}{$\begin{array}{l}\text { 気中暴露 } \\
\text { 期間（週） }\end{array}$} \\
\hline & & 塩水浸漬期間 & 乾燥期間 & サイクル数 & & \\
\hline (1) & \multirow{2}{*}{40} & 2 日間 & 4 日間 & 15 & - & 0,8 \\
\hline (2) & & 2 日間 & 4 日間 & 15 & 0,8 & - \\
\hline (3) & \multirow{6}{*}{50} & 2 日間 & 4 日間 & 15 & - & $0,4,8$ \\
\hline (4) & & 2 日間 & 4 日間 & 15 & $0,4,8$ & - \\
\hline (5) & & 2 日間 & 4 日間 & 10 & $0,4,8$ & - \\
\hline (6) & & 2 日間 & 4 日間 & 5 & $0,4,8$ & - \\
\hline (7) & & 1 日間 & 2 日間 & 15 & $0,4,8$ & - \\
\hline$(8)$ & & 8 時間 & 16 時間 & 15 & $0,4,8$ & - \\
\hline (9) & \multirow{2}{*}{60} & 2 日間 & 4 日間 & 15 & - & $0,1,4,8$ \\
\hline (10) & & 2 日間 & 4 日間 & 15 & $0,1,4,8$ & - \\
\hline
\end{tabular}

表-3 試験条件

\begin{tabular}{|c|c|c|c|c|c|}
\hline & & $\begin{array}{l}\text { 温度 } \\
\left({ }^{\circ} \mathrm{C}\right)\end{array}$ & $\begin{array}{c}\text { 相対湿度 } \\
(\%)\end{array}$ & $\begin{array}{c}\mathrm{NaCl} \text { 濃度 } \\
(\%)\end{array}$ & $\begin{array}{c}\mathrm{CO}_{2} \text { 濃度 } \\
(\%)\end{array}$ \\
\hline \multirow{2}{*}{$\begin{array}{c}\text { 乾湿 } \\
\text { 繰返 L } \\
\text { 条件 }\end{array}$} & $\begin{array}{l}\text { 塩 } \\
\text { 水 }\end{array}$ & 20 & - & 5.0 & - \\
\hline & $\begin{array}{l}\text { 乾 } \\
\text { 燥 }\end{array}$ & 40 & - & - & - \\
\hline \multicolumn{2}{|c|}{$\begin{array}{c}\text { 促進中性化 } \\
\text { 条件 }\end{array}$} & 20 & 60 & - & 5.0 \\
\hline \multicolumn{2}{|c|}{$\begin{array}{c}\text { 気中暴露 } \\
\text { 条件 }\end{array}$} & 20 & 60 & - & - \\
\hline
\end{tabular}

\section{3. 解析的検討}

\section{1 水の流れ}

水のダルシー流の支配方程式は，式(2)で与えられる。

$$
\frac{\partial \theta}{\partial t}=\frac{\partial}{\partial x_{i}}\left[K\left(K_{i j}^{A} \frac{\partial h}{\partial x_{j}}+K_{i y}^{A}\right)\right]-S
$$

ここで, $\theta$ は水量, $h$ は水頭, $S$ は生成項, $x_{i} \quad(i=1,2,3)$ は空閒座標, $t$ は時間, $K_{i j}^{A}$ は無次元異方性テンソル $\mathbf{K}^{A}$ の成分， $K$ は式(3) で与えられる不飽和透水係数である 15)

$$
K(x, h)=\left\{\begin{array}{lll}
K_{s}(x) K_{r}(x, h) & \text { if } & h<0 \\
K_{s}(x) & \text { if } & h \geq 0
\end{array}\right.
$$

ここで, $K_{r}$ は相対透水係数および $K_{s}$ は飽和透水係数であ る。相対透水係数は式(4) で表せる ${ }^{15)}$ 。

$$
K_{r}=\sqrt{S_{e}}\left[1-\left(1-\sqrt[m]{S_{e}}\right)^{m}\right] \quad S_{e}=\frac{\theta-\theta_{r}}{\theta_{s}-\theta_{r}}
$$

ここで， $\theta_{r}$ は貯留水量， $\theta_{s}$ は飽和水量である。不飽和多 孔質材料中の流れ問題を解くには，水量と圧力水頭 $h$ の間の関係を決定しなければならないが，この関係は，

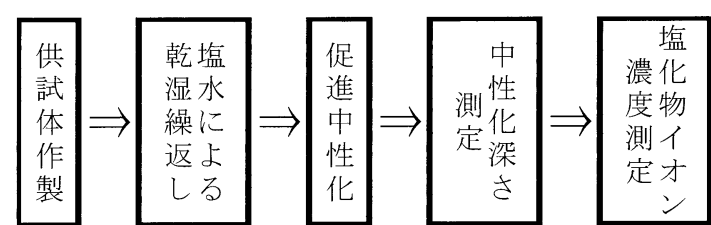

図-1 Series I の実験フロー図

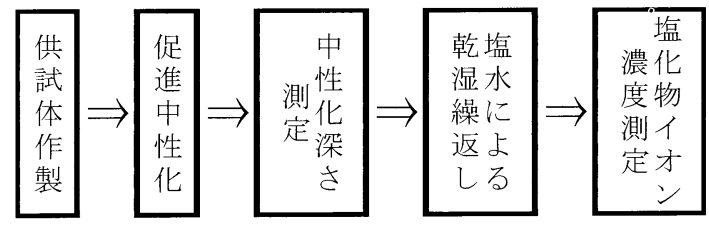

図-2 Series II の実験フロー図

式(5)で表す ${ }^{15)}$ 。

$\theta(h)=\left\{\begin{array}{lll}\theta_{r}+\frac{\theta_{s}-\theta_{r}}{\sqrt{\left.1+|\alpha h|^{n}\right]^{n}}} & \text { if } & h<0 \\ \theta_{s} & \text { if } \quad h \geq 0\end{array} \quad m=1-\frac{1}{n}, \quad n>1\right.$

ここで， $\alpha, n$ は材料パラメーターである。

\section{2 温度の影響}

また，物質移動に及ぼす水蒸気拡散の影響を無視する と，2次元熱移動は式(6)のように表すことが出来る。

$$
C(\theta) \frac{\partial T}{\partial t}=\frac{\partial}{\partial x_{i}}\left[\lambda_{i j}(\theta) \frac{\partial T}{\partial x_{j}}\right]-C_{w} q_{i} \frac{\partial T}{\partial x_{i}}
$$

ここで, $T$ は温度， $\lambda_{i j}(\theta)$ は材料の熱伝導係数, $C(\theta)$ お よび $C_{w}$ はそれぞれコンクリートと液体の容積熱容量を 表す。容積熱容量は, 密度と熱容量の積として定義され る。式(6)の右辺の第 1 項は伝導による熱の流れを, また 第 2 項は流水によって移動される熱を表す。上式では,

蒸気移動による潜熱の移動は考慮しない。

\section{3. $3 \mathrm{CO}_{2}$ の移動}

$\mathrm{CO}_{2}$ の移動現象を水中の対流と水中及び気相中の拡散 と考えると, $\mathrm{CO}_{2}$ の移動は, 式(7)に示す質量釣合式によ って支配される。 


$$
\frac{\partial C_{T}}{\partial t}=-\frac{\partial}{\partial x_{i}}\left(J_{d a i}+J_{d w i}+J_{c w i}\right)+P
$$

ここで, $J_{d a i}$ は気相中の拡散によって起こる $\mathrm{CO}_{2}$ 流量, $J_{d w i}$ は水中での拡散によって起こる $\mathrm{CO}_{2}$ 流量, また $J_{c w i}$ は水 中の対流によって起こる $\mathrm{CO}_{2}$ 流量である。 $C_{T}$ は $\mathrm{CO}_{2}$ の 濃度, また $P$ は $\mathrm{CO}_{2}$ の逸散・生成項である。各項は, 以 下のように定義できる。

$$
\begin{aligned}
& J_{d a i}=-\theta_{a} D_{i j}^{a} \frac{\partial C_{a}}{\partial x_{j}} \\
& J_{d w i}=-\theta_{a} D_{i j}^{w} \frac{\partial C_{w}}{\partial x_{j}} \\
& J_{c w i}=-q_{i} C_{w}
\end{aligned}
$$

ここで， $C_{w}$ および $C_{a}$ はそれぞれ水中および気相中の $\mathrm{CO}_{2}$ の濃度, $D_{i j}^{a}$ は気相中の $\mathrm{CO}_{2}$ の有効拡散係数テンソ ル, $D_{i j}^{w}$ は溶解相中の $\mathrm{CO}_{2}$ の有効拡散係数テンソル, $q_{i}$ は 細孔水流量, $\theta_{a}$ は空気容積である。全 $\mathrm{CO}_{2}$ 濃度 $C_{T}$ は, 気相と溶解相中の $\mathrm{CO}_{2}$ の和として定義される。

$$
C_{T}=C_{a} \theta_{a}+C_{w} \theta
$$

溶解相および気相中の $\mathrm{CO}_{2}$ の濃度は, 次式によって関係 づけられる。

$$
C_{w}=K_{c} C_{a}
$$

ここで， $K_{c}$ は温度に強く影響される分布定数である。化 学反応による $\mathrm{CO}_{2}$ の減少を考慮する項 $P$ は, 式(11) で与 えられる。

$$
P=-\alpha_{4} \frac{\partial\left[\mathrm{CO}_{2}\right]}{\partial t}
$$

ここで， $\alpha_{4}$ はコンクリートの特性によって 0 と 1 の範囲 で変化する無次元パラメータである。

\section{4 中性化}

水中に溶けてあるいはコンクリート細孔の気相中を通 つて拡散する $\mathrm{CO}_{2}$ は, 硬化セメントペーストの $\mathrm{Ca}(\mathrm{OH})_{2}$ のみならず, 珪酸カルシウム水和物 $\left(3 \mathrm{CaO} \cdot 2 \mathrm{SiO}_{2} \cdot 3 \mathrm{H}_{2} \mathrm{O}\right)$ および未水和珪酸塩 $\left(\mathrm{C}_{3} \mathrm{~S}\right.$ およ び $\left.\mathrm{C}_{2} \mathrm{~S}\right)$ とも反応するが，ここでは， $\mathrm{Ca}(\mathrm{OH})_{2}$ のみが中 性化反応に関係すると仮定する。従って, 主な中性化反 忘は式(12)によって表すことができる。

$$
\mathrm{Ca}(\mathrm{OH})_{2}+\mathrm{CO}_{2} \rightarrow \mathrm{CaCO}_{3}+\mathrm{H}_{2} \mathrm{O}
$$

この式は，中性化によって水酸化カルシウム（ポルトラ ンダイト）が炭酸カルシウム（カルサイト）となるメカ 二ズムを示すが, $\mathrm{pH}$ の変化や固定塩化物イオンの遊離を 直接説明できる全ての付随的な化学反応も考えなければ ならない。従って, コンクリートの炭酸化反応に関して
より包括的なモデル表示が必要となる。本解析では以下 の化学反応も考慮している。

$$
\begin{aligned}
& \mathrm{H}_{2} \mathrm{O} \longleftrightarrow \mathrm{H}^{+}+\mathrm{OH}^{-} \\
& \mathrm{H}_{2} \mathrm{CO}_{3} \longleftrightarrow \mathrm{H}^{+}+\mathrm{HCO}_{3}^{-} \\
& \mathrm{HCO}_{3}^{-} \longleftrightarrow \mathrm{H}^{+}+\mathrm{CO}_{3}^{2-} \\
& \mathrm{Ca}(\mathrm{OH})_{2} \longleftrightarrow 2 \mathrm{OH}^{-}+\mathrm{Ca}^{2+} \\
& \mathrm{CaCO}_{3} \longleftrightarrow \mathrm{CO}_{3}^{2-}+\mathrm{Ca}^{2+}
\end{aligned}
$$

\section{5 塩化物イオンの移動}

一方, コンクリート中の部分飽和水流条件における塩 化物イオンの移流・拡散移動の支配偏微分方程式は, 式 (14)で表せる。

$$
\frac{\partial \theta c}{\partial t}+\rho \frac{\partial \bar{c}}{\partial t}=\frac{\partial}{\partial x_{i}}\left[\theta D_{i j} \frac{\partial c}{\partial x_{j}}-q_{i} c\right]
$$

ここで, $\theta$ は水量, $c$ は自由塩化物イオンの濃度, $\bar{c}$ は 固定塩化物イオンの濃度， $\rho$ は媒体の密度， $D_{i j}$ は見か けの拡散係数テンソル， $q_{i}$ は流量である。固定塩化物イ オンと自由塩化物イオンの区分は, イオン交換選択の化 学的アプローチによって支配される。

不飽和条件での拡散係数は, 飽和度の関数として式 (15) で表せる ${ }^{16)}$ 。

$$
D\left(x, S_{e}\right)=\left\{\begin{array}{lll}
D_{s}(x) \mathrm{D}_{r}\left(x, S_{e}\right) & \text { if } & S_{e}<1 \\
D_{s}(x) & \text { if } & S_{e}=1
\end{array}\right.
$$

ここで, $\mathrm{D}_{r}\left(x, S_{e}\right)$ は相対拡散係数, また $D_{s}(x)$ は飽和拡 散係数である。相対拡散係数は式(16)で表せる ${ }^{16)}$ 。

$$
D_{r}\left(x, S_{e}\right)=\left(1+\frac{\left(1-S_{e}\right)^{4}}{\left(1-S_{c r}\right)^{4}}\right) \quad S_{e}=\frac{\theta-\theta_{r}}{\theta_{s}-\theta_{r}}
$$

ここで， $\theta_{r}$ は貯留水量, $\theta_{s}$ は飽和水量, また $S_{c r}$ は拡散 係数がその值の $50 \%$ にる時の飽和レベルである。

\section{6 塩化物イオンの固定と遊離}

塩化物イオンの固定化は, 塩化物イオンとセメント水 和物の間の化学反応の結果である。塩化物イオンの化学 的固定化の最終的な生成物は, フリーデル氏塩 ( $\left.3 \mathrm{CaO} \cdot \mathrm{Al}_{2} \mathrm{O}_{3} \cdot \mathrm{CaCl}_{2} \cdot 10 \mathrm{H}_{2} \mathrm{O}\right)$ である。これは, その成 分が $\left[\mathrm{Ca}_{2} \mathrm{Al}(\mathrm{OH})_{6} \cdot 2 \mathrm{H}_{2} \mathrm{O}\right]^{+} \cdot \mathrm{Cl}^{-}$であるもう一つの $\mathrm{AFm}$ 相である。イオン交換メカニズムは，水酸基 AFm 相の 層間に存在する水酸基イオンと, 細孔溶液中の塩化物イ オンあるいは外部から侵入してくる塩化物イオンとの 置き換えによって塩化物イオンが固定される。このイオ ン交換メカニズムは, 式(17) で表されるフリーデル氏塩 の形成を導く。

$$
\mathrm{R}^{+}-\mathrm{OH}^{-}+\mathrm{Cl}^{-} \rightarrow \mathrm{R}^{+}-\mathrm{Cl}^{-}+\mathrm{OH}^{-}
$$


ここで, $\mathrm{R}^{+}$は水酸基相 $\mathrm{AFm}, \quad\left[\mathrm{Ca}_{2} \mathrm{Al}(\mathrm{OH})_{6} \cdot 2 \mathrm{H}_{2} \mathrm{O}\right]^{+}$で ある。この交換反応の釣合定数は式 (18) で与えられる。

$$
K_{\mathrm{Cl}^{-} / \mathrm{OH}^{-}}=\frac{[\mathrm{R}-\mathrm{Cl}]\left[\mathrm{OH}^{-}\right]}{[\mathrm{R}-\mathrm{OH}]\left[\mathrm{Cl}^{-}\right]}
$$

固定される塩化物イオンの量は，この式とコンクリート のイオン交換容量(AEC)によって支配される。

中性化後, 炭酸イオン $\mathrm{CO}_{3}^{2-}$ と塩化物イオンは, 固定 塩化物イオンによって占められている交換場所をとりあ うことになる。2 価の炭酸イオンはカルシウムアルミネ 一ト水和物中の 1 価の塩化物イオンと強く結びつき，炭 酸塩アルミネート $\left(3 \mathrm{CaO} \cdot \mathrm{Al}_{2} \mathrm{O}_{3} \cdot \mathrm{CaCO}_{3} \cdot 11 \mathrm{H}_{2} \mathrm{O}\right)$ を生成 するためにそれらと置き換わる。水酸基 AFm 相の内部 の層で起こるこの交換反応は以下のようにまとめること ができる。

$$
2 \mathrm{R}-\mathrm{Cl}+\mathrm{CO}_{3}^{2-} \longleftrightarrow \mathrm{R}_{2}-\mathrm{CO}_{3}+2 \mathrm{Cl}^{-}
$$

ここで， $\mathrm{R}_{2}-\mathrm{CO}_{3}$ は $\left[\mathrm{Ca}_{2} \mathrm{Al}(\mathrm{OH})_{6} \cdot 2 \mathrm{H}_{2} \mathrm{O}\right]_{2}^{+} \cdot \mathrm{CO}_{3}^{2-}$ であ る。この交換反応の釣合定数は，次式によって与えられ る。

$$
K_{\mathrm{CO}_{3}^{2-} / \mathrm{Cl}^{-}}=\frac{\left[\mathrm{R}_{2}-\mathrm{CO}_{3}\right]\left[\mathrm{Cl}^{-}\right]^{2}}{[\mathrm{R}-\mathrm{Cl}]^{2}\left[\mathrm{CO}_{3}^{2-}\right]}
$$

塩化物イオンの炭酸イオンによる遊離に加えて, 塩化物 イオンの別の遊離メカニズムは，コンクリートの中性化 に伴う $\mathrm{pH}$ の低下に関係する。この塩化物イオン遊離は, 式(18)に示される釣合定数を満足するように $\mathrm{pH}$ の低下 が起こる限り，炭酸化作用がなくても起こりうる。本研 究では, 両方の遊離メカニズムが同時に満足される。

\section{7 数値計算}

コンクリートへの塩化物イオンの浸透と中性化の複合 作用を解析的に検討するには，上述した関係式を連成さ せて数值解析を行う必要があるが，ここではこれらを有 限要素法により行った。数值解析における環境条件は, 表-3 の試験条件を用いた。なお，気中の $\mathrm{CO}_{2}$ 濃度は
0.035\%とした。拡散係数と透水係数は，それぞれ土木学 会コンクリート標準示方書 ${ }^{17)}$ ，及び既往の研究 ${ }^{18)}$, 19), 20) のデータの平均值から求めた。数值計算で用いた各種係 数の一覧を表-4 に示す。交換反応 $\mathrm{KCl}^{-} / \mathrm{OH}^{-}$および $\mathrm{KCO}_{3}^{2-} / \mathrm{Cl}$ 並びにイオン交換容量(AEC)の算定については, 逆モデル 手法を用いた。すなわち，塩化物イオンと中性化の分布 形状からこれらの值を近似的に求めた結果, $\log \mathrm{KCl}^{\prime} \mathrm{OH}^{-}=$ $-1.9, \log K_{\mathrm{CO}_{3}^{2-} / \mathrm{Cl}^{\prime}}=8.3$, および $A E C=2 \mathrm{~mol} / \mathrm{dm}^{3}$ となり， これらの值を用いた。

熱伝導に関しては，以下の関係を用いた。

$$
\begin{aligned}
& \lambda_{i j}(\theta)=\lambda_{o}(\theta) \delta_{i j} \text { with }\left\{\begin{array}{c}
\delta_{i j}=1 \text { if } i=j \\
\delta_{i j}=0 \text { otherwise }
\end{array}\right. \\
& \lambda_{o}(\theta)=2.10+0.56 \theta \quad \mathrm{W} /(\mathrm{m} \mathrm{K})
\end{aligned}
$$

また，コンクリートと水の容積熱容量は以下の值を用 いた。

$$
\begin{aligned}
& C(\theta) \approx C_{c}\left(1-\theta_{s}\right)+C_{w} \theta \\
& C_{c}=2.42 \times 10^{6} \quad \mathrm{~J} /\left(\mathrm{m}^{3} \mathrm{~K}\right) \\
& C_{w}=4.18 \times 10^{6} \quad \mathrm{~J} /\left(\mathrm{m}^{3} \mathrm{~K}\right)
\end{aligned}
$$

気相中の $\mathrm{CO}_{2}$ 有効拡散係数は次式によった。

$$
\begin{aligned}
& \left(\theta_{s}-\theta\right) D_{i j}^{a}=\left(\theta_{s}-\theta\right) D^{a} \tau_{a} \delta_{i j} \\
& D^{a}=1.57 \times 10^{-5} \mathrm{~m}^{2} / \mathrm{s} \\
& \tau_{a}=\frac{\left(\theta_{s}-\theta\right)^{7 / 3}}{\theta_{s}^{2}}
\end{aligned}
$$

また, 液相中の $\mathrm{CO}_{2}$ 有効拡散係数は次式によった。

$$
\begin{aligned}
& \theta D_{i j}^{a}=\theta D^{w} \tau_{w} \delta_{i j} \\
& D^{w}=1.77 \times 10^{-9} \mathrm{~m}^{2} / \mathrm{s} \\
& \tau_{w}=\frac{\theta^{7 / 3}}{\theta_{s}^{2}}
\end{aligned}
$$

式(13)の化学反応に対応する熱力学定数は, 以下の值を 用いた。

表-4 数值計算で用いた各種係数

\begin{tabular}{|c|c|c|c|c|c|c|}
\hline $\mathbf{W} / \mathbf{C}$ & $\theta_{s}$ & $\theta_{r}$ & $\alpha$ & $\boldsymbol{n}$ & $\boldsymbol{K}$ & Ds \\
& $m^{3} / m^{3}$ & $m^{3} / m^{3}$ & $1 / m$ & $m / s$ & $m^{2} / s$ \\
\hline $\mathbf{0 . 4}$ & 0.1136 & 0.0000 & $1.07 \times 10^{-4}$ & 1.4056 & $4.5 \times 10^{-12}$ & $1.87 \times 10^{-12}$ \\
\hline $\mathbf{0 . 5}$ & 0.1483 & 0.0000 & $1.22 \times 10^{-3}$ & 1.3567 & $1.3 \times 10^{-11}$ & $4.41 \times 10^{-12}$ \\
\hline $\mathbf{0 . 6}$ & 0.1857 & 0.0000 & $3.82 \times 10^{-4}$ & 1.4412 & $9.1 \times 10^{-11}$ & $8.7 \times 10^{-12}$ \\
\hline
\end{tabular}




$$
\begin{aligned}
& \log K_{\mathrm{H}_{2} \mathrm{O}}=-14 \\
& \log K_{\mathrm{H}_{2} \mathrm{CO}_{3}}=-6.38 \\
& \log K_{\mathrm{HCO}_{3}^{-}}=-10.48 \\
& \log K_{{\mathrm{Ca} O \mathrm{OH})_{2}}}=-5.13 \\
& \log K_{\mathrm{CaCO}_{3}}=-8.38
\end{aligned}
$$

\section{4. 結果および考察}

\section{1各種条件が塩化物イオン浸透に及ぼす影響}

図-3に, Series I の塩水による乾湿繰返し作用を終え た時点における，水セメント比，サイクル数，繰返し周 期ごとの全塩化物イオン濃度分布を示す。なお，塩化物 イオン濃度は，コンクリート質量に対する塩化物イオン 質量の百分率で表わしている。これらの図より，水セメ ント比が大きいほど，サイクル数が多いほど，繰返し周 期が長いほど，塩化物イオンの浸透量は多くなっている ことがわかる。また，図-4に水セメント比，サイクル数， 繰返し周期ごとの固定塩化物イオン濃度分布を示す。こ れらの図より，水セメント比が大きいほど，サイクル数 が多いほど，繰返し周期が長いほど，表層の固定塩化物 イオン濃度は減少している。これは，乾湿の繰り返しに よる表層セメント水和物の変質により塩化物イオンが固 定化されにくくなったためと考えられる。

本環境作用条件における表面部の塩化物イオン浸透量

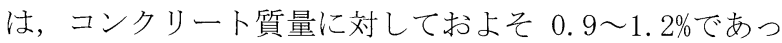
た。

\section{2 Series I の実験結果}

図-5に I -2) (W/C=40\%, 塩水浸漬 2 日 - 乾燥 4 日, 15 サイクル）の塩化物イオン濃度分布を示す。水セメント 比 $40 \%$ の場合, 中性化は進行してない。全塩化物イオン 濃度分布は 1 2 $\mathrm{cm}$ の層で若干の増加が見られるが, 中性 化が進行していないことから，中性化促進中の拡散が 1 つの要因と考えられるが，必ずしも明確でない。図-6に I -(4) (W/C $=50 \%$, 塩水浸漬 2 日 - 乾燥 4 日, 15 サイクル) の塩化物イオン濃度分布を示す。水セメント比が $50 \%$ に なると, 促進期間 8 週で $5.27 \mathrm{~mm}$ の中性化深さを確認する ことができ, 表層の固定塩化物イオン濃度が中性化 8 週 で，38.7\%減少した。これは中性化の進行によってフリー デル氏塩などの固定塩化物イオンが遊離されたためと考 えられる。また, 全塩化物イオン濃度分布も中性化 8 週 で表層と 1 2cm の層で減少しているが $2 \sim 3 \mathrm{~cm}$ の層では 27. 6\%の増加が見られる。図-7に I-10) (W/C=60\%, 塩水 浸漬 2 日 - 乾燥 4 日, 15 サイクル) の塩化物イオン濃度 分布を示す。水セメント比が $60 \%$ になると，促進期閒 8 週で $7.18 \mathrm{~mm}$ の中性化深さを確認することができた。表層 の固定塩化物イオンはほとんど遊離されている。全塩化 物イオン濃度分布は $3 \sim 4 \mathrm{~cm}$ の層で若干増加が見られる ものの，塩化物イオンの内部への進行現象は全体として 明確に現れなかった。解析は, 本実験結果の全体的な挙 動を捉えていると言える。

\section{3 Series II の実験結果}

図-8 に II-(2)（W/C=40\%，塩水浸漬 2 日 - 乾燥 4 日， 15 サイクル）の塩化物イオン濃度分布を示す。この場合,

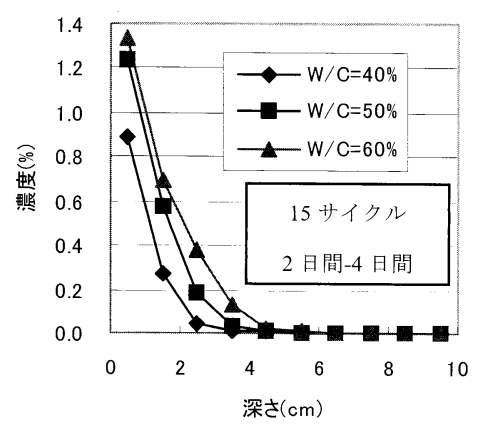

図-3＼cjkstart繰返し条件別の全塩化物イオン濃度分布

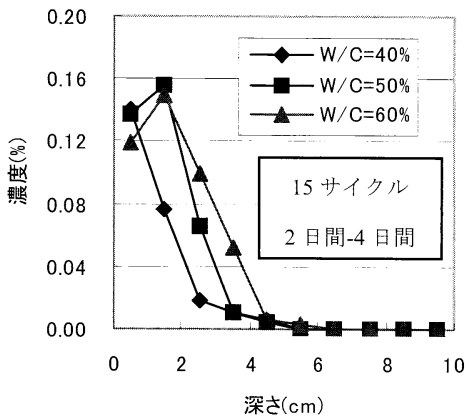

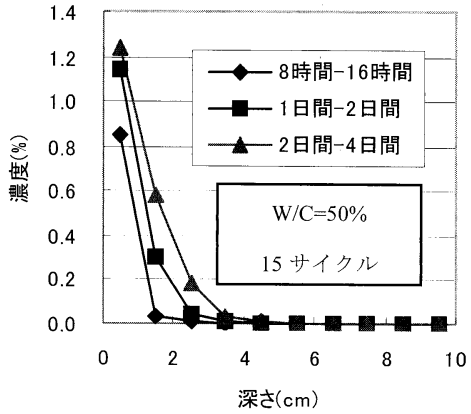

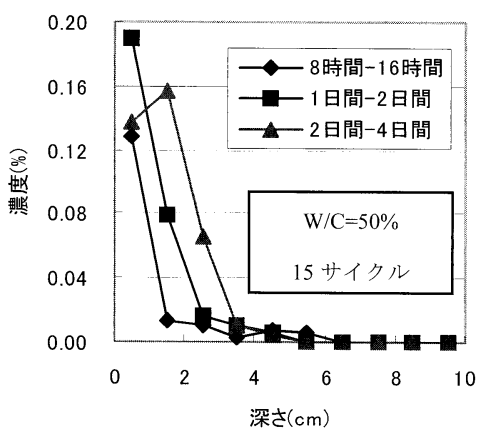

図-4 繰返し条件別の固定塩化物イオン濃度分布 

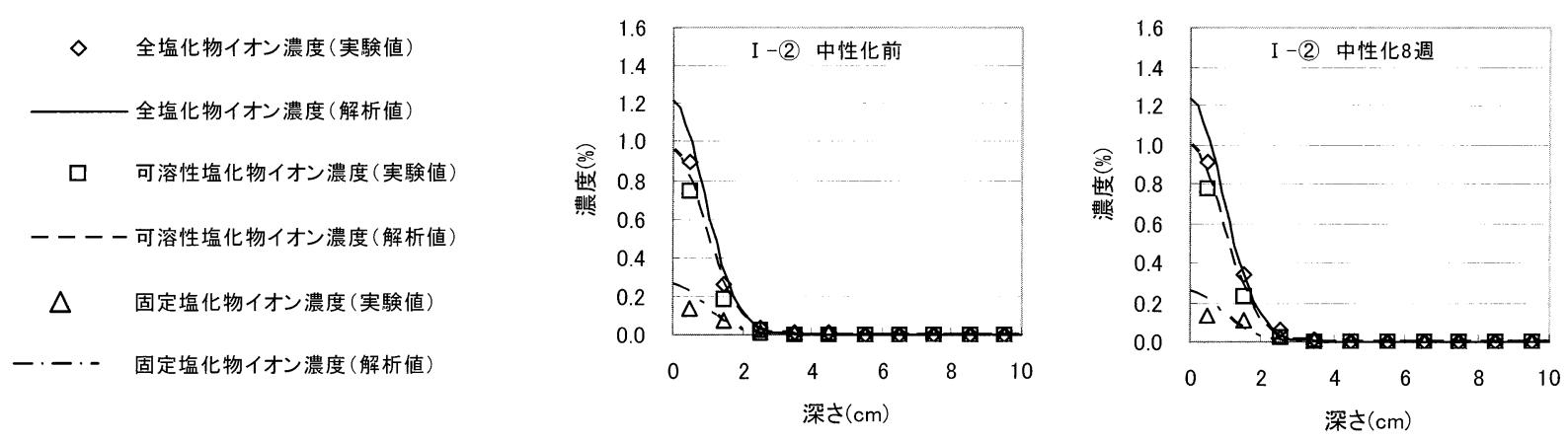

図-5 中性化前と中性化 8 週における塩化物イオン濃度分布（ I - (2)

中性化深さは確認されなかった。全塩化 物イオン濃度は, 中性化を 8 週促進させ てから塩水による乾湿繰返しを行った方 が塩化物イオンが多く浸透している。こ れは, 中性化促進期間中に供試体内部の 水分が逸散し, 塩水が浸入しや寸くなっ たためと考えられる。

図-9に II-(4)（W/C=50\%，塩水浸漬 2 日 一乾燥 4 日，15 サイクル）の塩化物イオ ン濃度分布を示す。中性化深さは促進期 間 8 週で $7.12 \mathrm{~mm}$ であった。表層では, 塩化物イオンは中性化 8 週でほとんど固 定されていないことがわかる。また，全 塩化物イオン濃度分布は, II-(2)の場合 とは逆に中性化を 8 週間促進させてから 塩水による乾湿繰返しを行った方が表 層では少なくなり, その次の 1 2 $2 \mathrm{~cm}$ の 層で増加していることがわかる。表層で は中性化を8 週促進させることによって 34. 6\%減少し，1〜2 $\mathrm{cm}$ の層で 7. $0 \%$ 増加し ている。

図-10にII-(10)（W/C=60\%，塩水浸漬 2 日一乾燥 4 日, 15 サイクル) の塩化物イオン濃度分布を 示す。中性化深さは促進期間 8 週で $11.2 \mathrm{~mm}$ であった。 表層の固定塩化物イオンは II-(4)と同様にほとんど固定 されていない。また, 全塩化物イオン濃度分布も川-(4) と同様に中性化を 8 週促進させることによって, 表層で は少なくなるが，その次の層で増加している。表層では
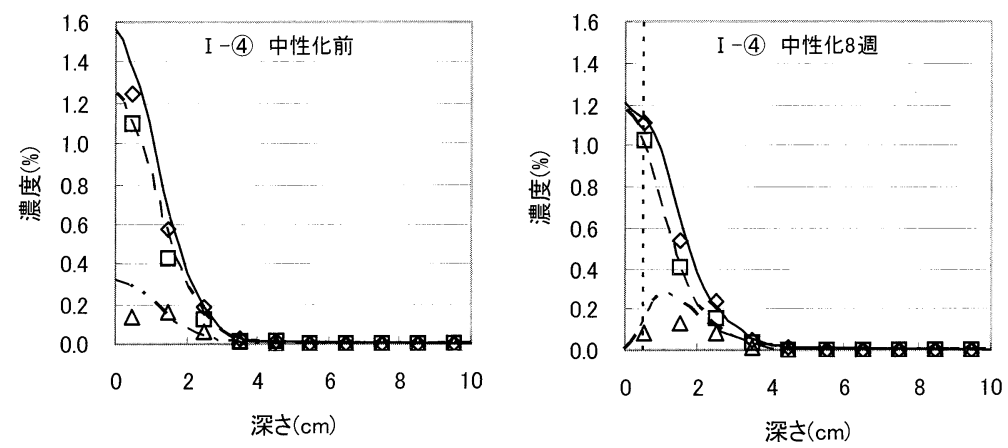

図-6 中性化前と中性化 8 週における塩化物イオン濃度分布（I - (4)
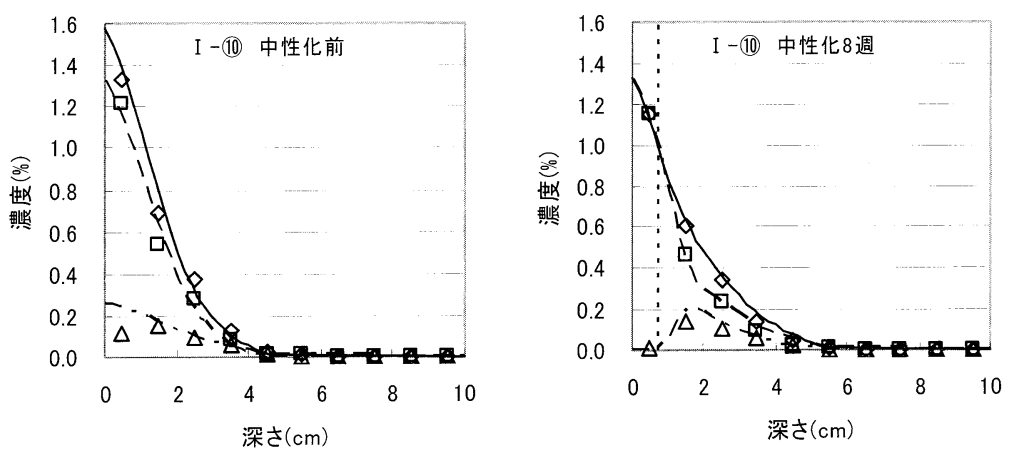

図-7中性化前と中性化 8 週における塩化物イオン濃度分布（I－10）
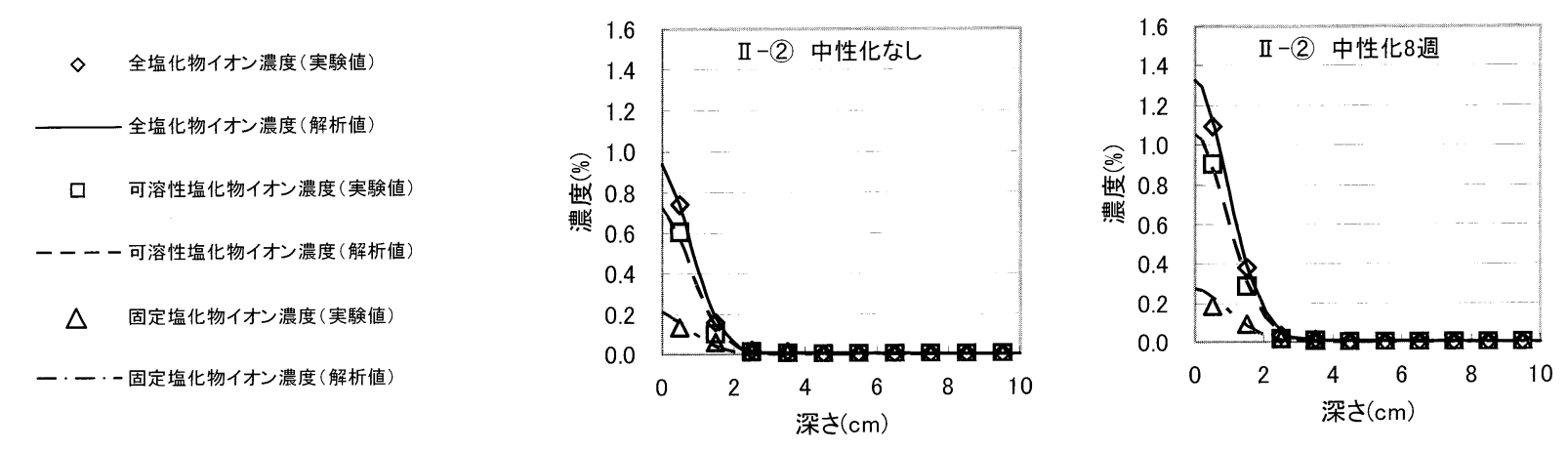

図-8 中性化なしと中性化 8 週における塩化物イオン濃度分布（II-(2)） 
内部に拡散が起こったと考えられる。

この場合についても，解析結果は実験結 果の傾向を抢抢よそ捉えていると考えられ る。

\section{4 細孔径分布}

図-11に, Series I の中性化の有無による 表層の細孔径分布の違いを示す。測定に用い たコンクリートは, 水セメント比 $60 \%$ で塩水 浸漬 2 日, 乾燥 4 日の乾湿繰返しを 15 サイ クル行ったもので, その後, 気中暴露 4 週行 った場合（I-99) と促進中性化を 4 週行っ た場合（I -(10) で比較する。中性化を 4 週 促進させた場合は気中暴露の場合と比べて, $0.01 \mu \mathrm{m} \sim 0.05 \mu \mathrm{m}$ の範囲の細孔径が減少 し, $0.05 \mu \mathrm{m} \sim 0.3 \mu \mathrm{m}$ の範囲の細孔径が増加 している。つまり, 中性化を 4 週させた方が 一部細孔径が粗大になることがわかる。一般 的にコンクリートの中性化領域では中性化 していない場合に比べて炭酸カルシウムな どの生成物によって組織構造が緻密化する といわれている。しかし, 本実験結果では逆
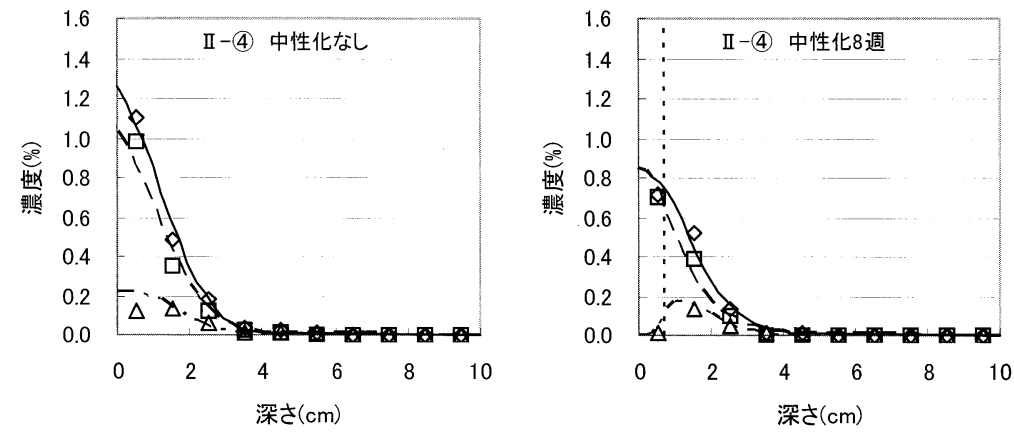

図-9 中性化前と中性化 8 週における塩化物イオン濃度分布（II-(4)

になる領域が存在する結果になった。これ

は, 固定塩化物イオンが中性化により遊離して細孔溶液に溶出 寸ることにより一部細孔径が粗大化したと類推される。

図-12 に, Series II の中性化の有無による表層の細孔径分布 の違いを示寸．測定に用いたのは水セメント比 $60 \%$ で気中暴露

（II-(9)）および促進中性化（II-(10）を 4 週行った後, 塩水浸 漬 2 日, 乾燥 4 日の乾湿繰返しを 15 サイクル行ったものであ る。中性化を 4 週促進させた場合は気中暴露の場合と比べて, $0.003 \mu \mathrm{m} \sim 0.02 \mu \mathrm{m}$ の範囲の細孔径が増加している. つまり, 中性化を 4 週させた方が小さい細孔径の容積が増加すること がわかる。中性化を行ったものは塩化物イオンが固定化されな いにもかかわらず, 塩化物イオンが固定化されている気中暴露 の場合よりも緻密になる結果となっている。これは, 塩化物イ オンの固定化よりも中性化の方がコンクリートの緻密化に与 える影響が大きいものと考えられる。

\section{5 全塩化物イオン濃度と固定塩化物イオン濃度の関係}

図-13に全塩化物イオン濃度と固定塩化物イオン濃度の関係 を示寸。図-13（a）に示寸様に，中性化前の塩化物イオンの固 定量は, 全塩化物イオン濃度が約 $0.48 \%$ までは比例的に増加し, 0.48\%以降は固定塩化物イオン濃度は約 $0.138 \%$ で一定状態とな る。全塩化物イオン濃度が大きい領域ではばらつきが見られる ものの, 塩化物イオンの固定量には上限值があると考えられ る。本研究によって得られた塩化物イオンの固定量と全塩化物 イオンの関係は以下のようになる。

$$
\begin{aligned}
& \mathrm{Cl}_{\mathrm{F}}=0.2896 \mathrm{Cl}_{\mathrm{T}}\left(\mathrm{Cl}_{\mathrm{T}}<0.48 \%\right) \\
& \mathrm{Cl}_{\mathrm{F}}=0.138 \quad\left(\mathrm{Cl}_{\mathrm{T}} \geqq 0.48 \%\right)
\end{aligned}
$$

ここで, $\mathrm{Cl}_{\mathrm{F}}$ : 塩化物イオンの固定量の上限值 $(\%), \mathrm{Cl}_{\mathrm{T}}$ : 全塩化 物イオン濃度 $(\%)$

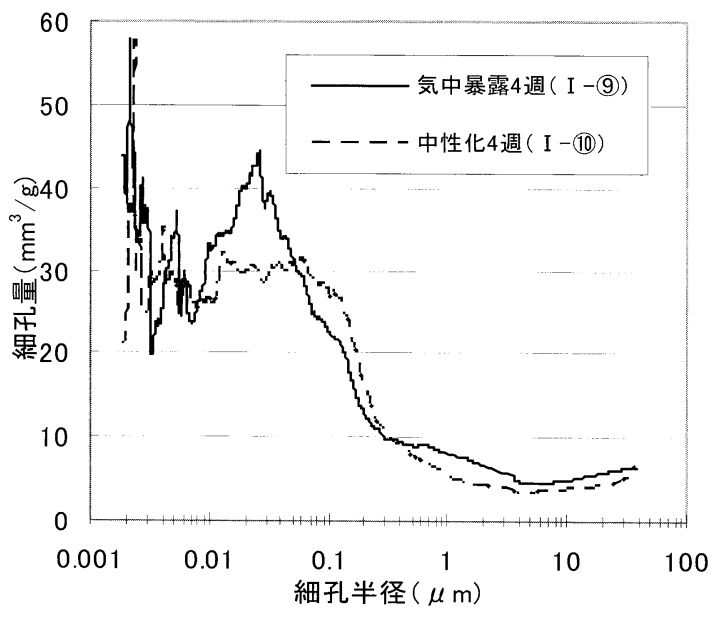

図 -11 細孔径分布 (Series I)

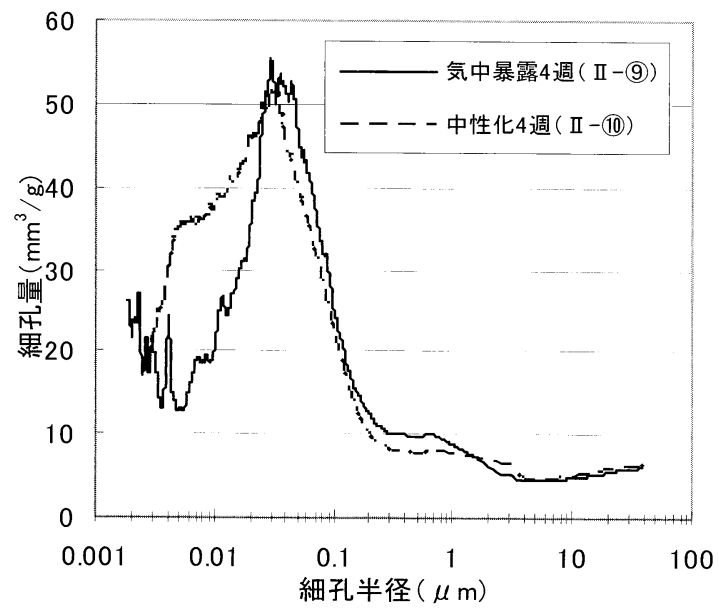

図-12 細孔径分布 (Series II ) 
コンクリート中の塩化物イオンはセメント質量の約 $0.4 \%$

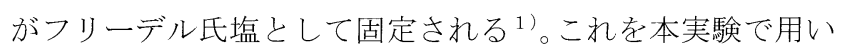
たコンクリート質量に換算すると, 約 $0.06 \%$ ガフリーデル氏 塩として固定されており, 残りの約 0.078\%は C-S-H などの 層間に吸着している吸着塩化物イオン ${ }^{9)}$ と考えられる。

図-13(b)に, Series I の中性化 8 週における全塩化物イ オン濃度と固定塩化物イオン濃度の関係を示す。データに ばらつきはあるが，中性化を受けない場合と比べて全体と して固定塩化物イオン濃度が低下することがわかる。平均 值は約 0.068\%である。また，図-13(c)に, Series IIの中性 化 8 週後に塩水による乾湿の繰り返しを作用させた場合の 全塩化物イオン濃度と固定塩化物イオン濃度の関係を示 す。中性化を促進させておくことによって塩化物イオンが ほとんど固定されないことがわかる。

\section{5. 塩化物イオンの侵入と中性化の複合作用の評 価方法の検討}

\section{1 中性化の影響を考慮に入れた評価方法の提案}

ここでは，本実験結果に基づいて式（1）に示す Fickの第 2 法則に基づく拡散方程式の解に中性化による複合作用の 影響を導入する方法を検討する。

図-14に，I -(10)（W/C=60\%，塩水浸漬 2 日一乾燥 4 日を 15 サイクル）の中性化 4 週の全塩化物イオン濃度分布と I - (9)

$(\mathrm{W} / \mathrm{C}=60 \%$ ，塩水浸漬 2 日一乾燥 4 日を 15 サイクル）の気中 4 週の全塩化物イオン濃度分布を示す。図より, 中性化を 4 週促進させた I-10は, 塩化物イオンの遊離により, 中性化 をさせない I--(9)より塩化物イオンの内部拡散が進んだと考 えることができる。

まず，I-9)(気中暴露 4 週）の表面における塩化物イオ ン濃度 $C_{0}$ を $1.4 \%$ と仮定する. 次に拡散係数 $D_{d}$ を土木学会 コンクリート標準示方書 ${ }^{17)}$ に示されている式（30）によっ て水セメント比 $(60 \%)$ から求めると, $D_{d}=2.61\left(\mathrm{~cm}^{2} /\right.$ 年 $)$ とな る。

$$
\log D_{d}=-3.9(\mathrm{~W} / \mathrm{C})^{2}+7.2(\mathrm{~W} / \mathrm{C})-2.5
$$

以上のようにして求めた表面塩化物イオン濃度および拡散 係数を式（1）に代入し，実験データに近似するように暴露 期間 $t$ を求めると, 約 0.7 年になった。

次に，I－(10)（中性化 4 週）の表面における想定塩化物イ オン濃度 $C_{0}$ を I-(9) と同様に $1.4 \%$ とし，拡散係数も同様に $2.61 \mathrm{~cm}^{2} /$ 年としてこれらを式 (1) に代入して実験データを 近似するように暴露期間 $t$ を求めると, 約 1 年になった。

つまり，中性化を促進させることにより中性化がない場 合の約 1.4 倍の速さで塩化物イオンが内部に移動すること を意味する。そこで式（31）のように，式（1）に中性化の 影響を考慮する係数 $k$ を暴露期間 $t$ に乗じることによって 塩化物イオン浸透の促進倍率とした。本来はそのメカニズ ムに基づいたモデル化を行うべきであるが，ここでは複合 効果を簡易に扱う 1 つの方法として提案することとした。
- Series I $-W / C=40 \%$ Series I $-W / C=50 \%$ Series I $-W / C=60 \%$ จ Series II $-W / C=40 \%$ 口 Series II $-W / C=50 \% \Delta$ Series II $-W / C=60 \%$

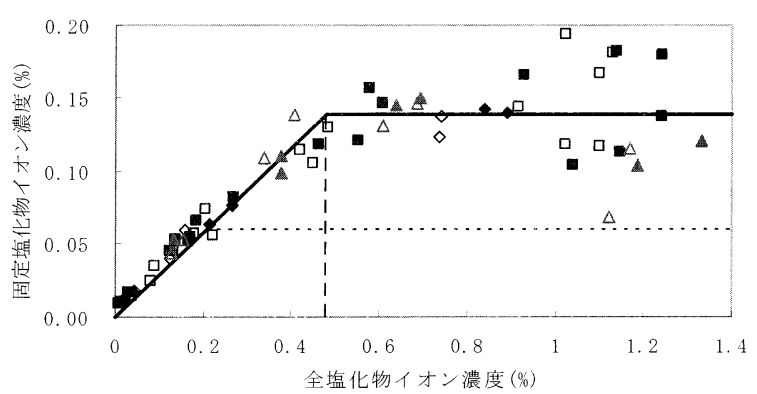

(a)中性化な L

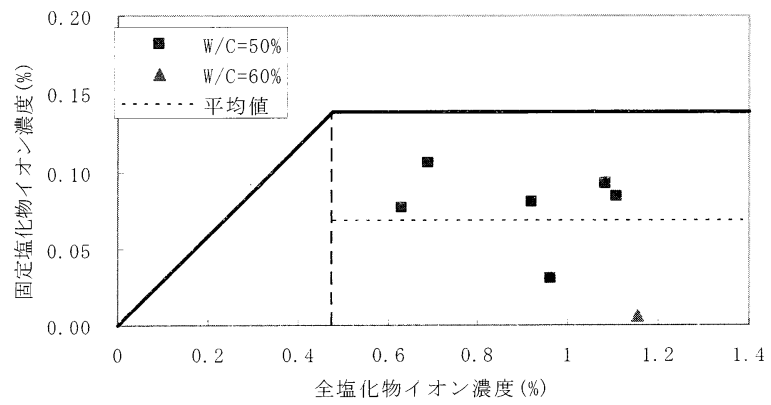

(b)中性化 8 週（Series I）

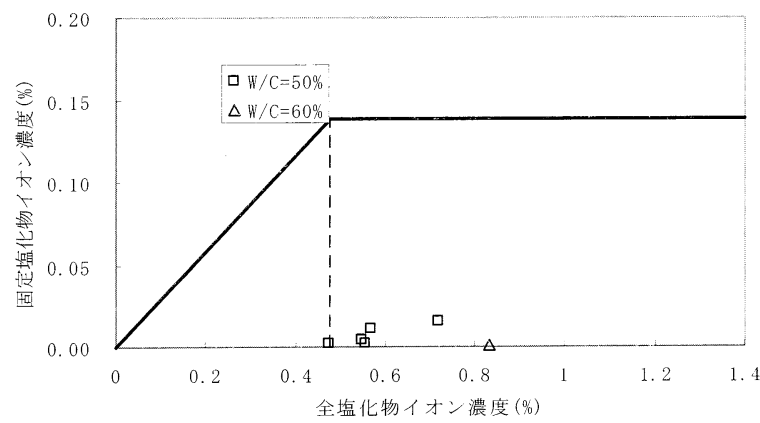

(c)中性化 8 週（Series II）

図-13＼cjkstart全塩化物イオン濃度と固定塩化物イオン濃度の関係

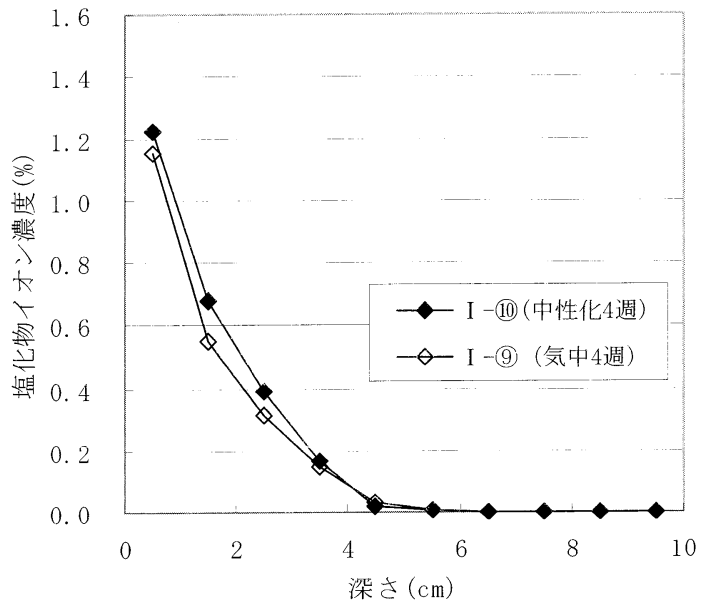

図-14 塩化物イオンの濃縮 
図-15に, 計算結果と実験值との比較を示す。

$$
C_{d}=C_{0}\left\{1-\operatorname{erf}\left(\frac{c}{2 \sqrt{D_{d} \cdot k \cdot t}}\right)\right\}
$$

\section{2 実構造物への適用}

次に, この手法を谷川ら ${ }^{21)}$ による実大 $\mathrm{RC}$ 構造物の実 測データに適用してみる。この構造物は, 沖縄県の海岸に 暴露されている。コンクリートの水セメント比は $63 \%$ で あり，拡散係数は式(30)により求めると $3.08 \mathrm{~cm}^{2} /$ 年であ る。この研究で示されたデータはコンクリート質量に対す る可溶性塩化物イオン濃度であり,ここではこのデータを 本研究と対応させるため, コンクリート質量に対する全塩 化物イオン濃度に換算した。 5 年間暴露された場合のコン クリートの表面における塩化物イオン濃度 $C_{0}$ を $1.5 \%$ と仮 定すると, 任意の深さにおける塩化物イオン濃度は次式の ように表すことができる。

$$
C_{d}=1.5\left\{1-\operatorname{erf}\left(\frac{c}{2 \sqrt{3.08 \cdot 5 \cdot k}}\right)\right\}
$$

式（32）において $k=1$ を考えると図-16 に示寸破線とな る。この場合, 谷川らによる実測值に対して, 破線で示さ れた曲線は過小評価していることがわかる。谷川らは実測 值の表層よりもその次の層で塩化物イオン濃度がピーク を示していることについて，中性化の影響を挙げている。 そこで中性化の影響を考慮した係数 $k$ を変化させて, 実測 值に近似させたのが実線になる。この場合， $k$ は 2.1 とな った。

以上のように, 中性化による塩化物イオン濃縮を考慮す るための係数 $k$ を塩化物イオンの算定式に導入すること が可能であることを示したが， $k$ の值は各種条件によって 変わることは明らかであり, 今後多くの実データを用いた 詳細な検討が必要である。

\section{6. まとめ}

コンクリートの塩害と中性化の複合作用に関する検討 を行った。本研究で得られた結果をまとめると以下の通り である。

(1) 水セメント比が大きいほど, 乾湿繰返しサイクル数が 多くなるほど，繰返し周期が長くなるほど，塩化物イ オンは内部に浸透するが, 固定塩化物イオンは表層で 少なくなる。これは，乾湿の繰り返しによる表層セメ ント水和物の変質によるものと考えられる。

(2) 塩化物イオンを浸透させてから中性化を促進させた 場合, 水セメント比 50\%, 60\%の場合において, 若干の 濃縮現象が見られた。

（3）中性化を促進させてから塩化物イオンを浸透させた 場合, 水セメント比 $50 \%, 60 \%$ の場合において, 中性化

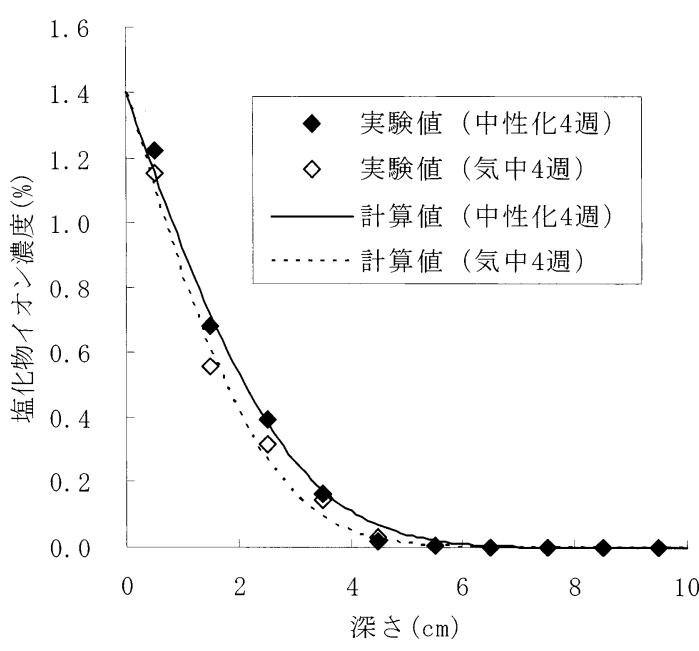

図-15計算結果と実験值の比較

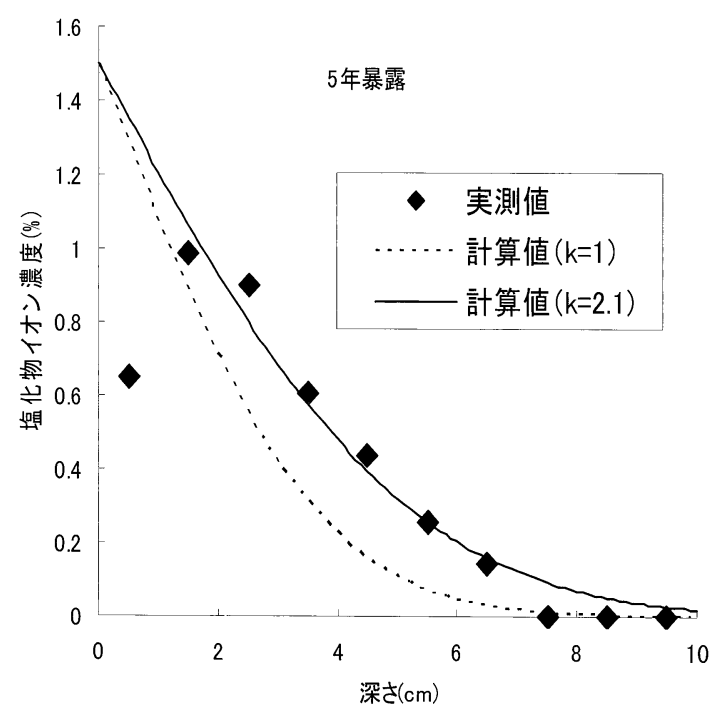

图-16 実測データと計算値の比較（5 年暴露）

が進行しているほど表層の全塩化物イオンは少なく なり，その次の層では増加している。これは，中性 化により表層は緶密化して塩化物イオンは侵入しに くいが，固定化されないことによって濃度勾配が大 きくなり，内部に搪散したと考えられる。

(4) 本論文で示した解析手法により, 本実験結果の全体 的な挙動を捉えることができる。

(5) 細孔構造は, 固定塩化物イオンが遊離することによ り，多孔質化する領域が存在する。

(6) 全塩化物イオン濃度と固定塩化物イオン濃度の関倸 から，塩化物イオンの固定量には上限がある。

（7）塩化物イオンを浸透させてから中性化を行った場 合, 遊離により固定塩化物イオン濃度は小さくなり, 中性化を先行させた場合には, 塩化物イオンはほと んど固定化されない。

（8）塩化物イオンの浸透と中性化の複合作用の影響は, 塩化物イオン濃度の算定式中の暴露期間 $t$ に塩化物 イオン浸透促進倍率係数 $k$ を乗じることによって評 
価することが可能である。各種条件下における $k$ 值の 詳細については今後検討する必要がある。

\section{参 考 文 献}

1) 小林一輔 : コンクリートの炭酸化に関する研究, 土木学会論文集, No. 433 , V-15, pp. $1 \sim 14,1991.8$

2) 佐伯竜彦・植木聡・嶋毅 : 塩害と中性化の複合による塩化物イオン の浸透予測モデルの構築, 土木学会論文集, No. $697 / \mathrm{V}-54$, pp. 131-142, 2002. 2

3) Mohamed Boulfiza, Koji Sakai, Nemkumar Banthia and Hidenori Yoshida, Analytical Study on Synergistic Effects of Carbonation and Chloride Ion Attack on Concrete, コンクリート工学年次論文集, Vol.23, No.2, pp.439-444, 2001

4) Mohamed Boulfiza, Koji Sakai, Nemkumar Banthia and Hidenori Yoshida, Prediction of Chloride Ions Ingress in Uncracked and Cracked Concrete, ACI Materials Journal, Vol.100, No.1, pp.38-48, 2003

5 ）桝田佳寛・天沼邦一・吉崎芳郎・御所窪邦男：コンクリートの乾湿 にともなう塩化物の移動について, コンクリート工学年次論文報告 集, Vol. 14, No. 1, pp. 787-792, 1992

6）掛川勝・栘田佳寛・松林祐二：セメントモルタル硬化体中の塩化物 イオンの移動に関する実験, コンクリート工学年次論文報告集, Vol. 16, No. 1, pp. 995-1000, 1994

7 ）佐伯竜彦・嶋毅・長瀧重義 : 等価拡散係数を用いたコンクリートの 塩分浸透予測手法の検討, コンクリート工学年次論文報告集, Vo1. 20, No. 2, pp. 859-864, 1998

8）佐伯竜彦・植木聡・嶋毅：コンクリート表面における塩化物イオン 濃度に関する検討，コンクリート工学年次論文報告集，Vol.21， No. 2, pp. 985-990, 1999

9）田中秀治・古賀祐久・河野広隆：各種セメントを用いたモルタルの 塩化物イオン固定量に関する研究, コンクリート工学年次論文報告 集, Vol.26, No. 1, pp. 843-848, 2004
10）前田聡・武若耕司・山口明伸：塩害データベースを用いたコンクリ 一下中人の塩化物イオン拡散の定量評価, 土木学会論文集, No. $760 /$ V-63, pp. 109-120, 2004.5

11）青山實伸 ・鳥居和之・松田哲夫：厳しい塩分環境下におけるコンク リート構造物の塩分浸透性に関する実証的研究, 土木学会論文集, No. 746/V-61, pp. 251-264, 2003. 11

12）笹谷輝彦・鳥居和之・佐藤健一・川村満紀 : 海洋環境化におけるコ ンクリートへの塩化物イオン浸透性の評価に関する研究, 土木学会 論文集, No. 571/V-36, pp. 91-104，1997.8

13）丸屋剛・Somnuk TANGTERMSIRIKUL・松岡康訓：コンクリート表層部 に㧍ける塩化物イオンの移動に関するモデル化，土木学会論文集， No. $585 / \mathrm{V}-38$, pp. $79-95,1998.2$

14）JCI 文献調査委員会 (担当：平尾宙), セメントによる塩化物イオン の固定に関する研究, コンクリート工学, Vol. 42, No. 11, pp. 55-61, 2004

15) J. Bear, Dynamics of Fluids in Porous Media, Dover Publications, 1988

16) A. Saetta, R. Scotta, and R. Vitaliani, Analysis of Chloride Diffusion into Partially Saturated Concrete, Materials Journal, ACI, Vol.90, No.5, pp.441-451, 1993

17）土木学会：コンクリート標準示方書「施工編」，2002 制定

18) R. Cerny and P. Rovnanikova, Transport Processes in Concrete. Spon Press 2002

19) A.S. El-Dieb and R.D. Hooton, Water Permeability Measurement of High Performance Concrete Using High Pressure Triaxial Cell, Cement and Concrete Research, 25, pp.1199-1208, 1995

20) C.M. Aldea, S.P. Shah and A. Karr, Permeability of Cracked Concrete. Materials and Structures, 32, pp.370-376, 1999

21）谷川伸・山田義智・大城武：塩害環境下におけるコンクリート中の 塩分蓄積量に関する一考察，コンクリート工学年次論文報告集， Vol. 18, No. 1, pp. 939-944, 1996

（原稿受理年月日：2005 年 3 月 28 日）

Evaluation of Synergistic Effects due to Penetration of Chloride Ion into Concrete and Carbonation By Koji Sakai, Masaki Omori and Mohamed Boulfiza

Concrete Research and Technology, Vol.17, No.2, May 2006

Synopsis: The study on quantitative evaluation with concrete about synergistic effect of penetration of chloride ion and carbonation, is very few. This study was conducted to get information on synergistic effects of penetration and diffusion of chloride ion into concrete and carbonation and to examine evaluation method of synergistic effects of penetration of chloride ion and carbonation. The test results indicated chloride ions in concrete diffused inside by carbonation and chloride ions penetrated for longer term than actual exposure term were accumulated. And so we introduced a coefficient $k$ to consider the effect of carbonation in diffusion equation which is based on the Fick's second law.

Keywords: Chloride ion, Carbonation, Synergistic effect, Fick’s diffusion equation 